\title{
THE DOCTRINE OF “JOINT CRIMINAL ENTERPRISE”: CRIMINAL LIABILITY OF THE MILITARY-POLITICAL LEADERSHIP OF THE ARMED CONFLICT OPPOSING PARTY FOR COMMITTING WAR CRIMES
}

\begin{abstract}
The article analyzes the mechanisms of bringing the military and political leadership of the opposing party of the armed conflict to criminal liability through the doctrine of "joint criminal enterprise", which is used in international criminal law, considering that the acts committed by this category of individuals, as a rule, are subject to investigation by international criminal tribunals based on definitions developed by international practice. The analysis carried out by the Author also enables to propose scientifically substantiated recommendations on the qualification of the acts conducted by the military and political leadership of the opposing party, which form corpus delicti of various military and international crimes according to the rules of complicity provided for by the national legislation of the Republic of Armenia.
\end{abstract}

Keywords: international crimes, international criminal law, international criminal court, qualification of war crimes.

"Mankind must put an
and to war before war puts
and to mankind."

John F. Kennedy

Throughout history, people fought with each other. During five and a half millennia of the human civilization history, about 15 thousand warriors and armed conflicts occurred in which 3.5 billion people died. In the entire history of existence, people lived in peace for only 292 years, i.e. less than one week every hundred years (Vakhrushev, 1999, pp. 20-28). Consequently, the problem of war fell into the subject field of philosophy at the very beginning of its development. Some reject the very idea of the "morality of war". Of those, some deny that morality applies at all once the guns strike up; for others, no

plausible moral theory could license the exceptional horrors of war (Seth, 2020).

The commission of war crimes would not have been possible without the participation of high-level officials, since they are the ones who develop plans and give orders. Therefore such persons should be more culpable than subordinates who factually committed the criminal act ${ }^{1}$. However, the problem of bringing such persons

\footnotetext{
See International Law Commission, R. (1996). Commentary to Art.7 of the Draft Code of Crimes Against the Peace and Security of mankind of 5 July 1996. UN Doc A/51/10. Yearbook of the International Law Commission.Vol. II (2).
} 
to criminal liability derives from the fact that representatives of the military-political leadership of States do not directly participate in the commission of war crimes.

In order to achieve these objectives, as well as to determine the circle of persons subject to liability and for the correct qualification of acts it is necessary to consider the forms and types of participation in war crimes that are implicated by international criminal law since acts committed by this category of persons usually become the subject of an investigation by international criminal justice authorities based on definitions developed by international practice.

In International criminal law, individual criminal responsibility is provided for a person both for the direct commission of international crimes and for other complex forms of complicity aimed at the realization of a common purpose, plan or project, including indirect forms of participation to facilitate the commission of a crime, where the individual does not necessarily have to share the intent of the accomplices.

The provisions that the person who planned, instigated, ordered, committed or otherwise aided and abetted the planning, preparation or commission of a crime, is personally responsible for this crime, are reflected in almost identical articles of all the statutes of international courts.

Thus, 5 types of participation in crime are described: commission, ordering, planning, instigating, as well as aiding and abetting.

The decisive importance in considering cases involving the prosecution of persons occupying high-level positions in the military-political hierarchy of States such form of participation as the "joint criminal enterprise" (hereinafter JCE) developed by the International Criminal Tribunal for the Former Yugoslavia (hereinafter ICTY), which was subsequently used by the Internation- al Criminal Tribunal for Rwanda ${ }^{2}$ (hereinafter ICTR), the Special Court for Sierra Leone, including used concerning the President of Liberia Charles Taylor ${ }^{3}$, and subsequently laid the foundation of the modern understanding of this doctrine and now, camouflaged reflected in paragraph (d) Part 3 of Article 25 of the Rome Statute of the International Criminal Court (hereinafter ICC). By its nature, it is close, but not identical to the concepts of "organized criminal group" and "criminal community" used in the Armenian criminal law.

The essence of the doctrine of "common purpose" is that several criminals work together to achieve the goal, not stopping before committing crimes. In the ICTY Statute, this concept is implemented in the word "order". The ICTY Appeals Chamber, which has considered the Tadić case ${ }^{4}$ has proposed that this legal principle be applied in cases where the highest political leaders are members of a criminal group to commit international crimes, based on the following provision: "The Statute of the International tribunal states jurisdiction over all persons who planned, instigated, ordered, physically committed or otherwise aided and abetted in the planning, preparation or execution of a crime. It does not exclude those modes of participating in the commission of crimes which occur when several persons of common purpose embark on criminal

2 ICTR. (13 December, 2004). MTR. Resheniye appelyacionnoy cameri po delu Natakirutimana i dr. (ICTR: Judgment of the Appeals Chamber on Ntakirutimana and others case, in Russian).Paragraph 467-484.

3 SCSL. (7 March, 2003). SSSL: Prokuror protiv Charlza Teylora (SCSL: Prosecutor versus Charles Taylor (Case number SCSL-03-01-PT), Indictment Act).

4 ICTY.(15 June, 1999). MTBY: resheniye appelyacionnoy cameri po delu Tadicha (ICTY: Judgment of the Appeals Chamber on Tadic case, in Russian). Paragraph 190; ICTY. (2 November, 2001). MTBY: resheniye appelyacionnoy cameri po delu Kvochki (Judgement of the Appeals Chamber on Kvocki and others case, in Russian). Paragraph 255. 
activity that is then carried out either jointly or by some members of this plurality of persons".

The ICTY argued that JCE is not a definition of a new crime, it is an explication of the principle of criminal responsibility contained in the word "committed" which is used in the Statute. However, the Court stated that criminal responsibility arising from participation in the JCE is not equivalent to "the guilt by association". The Tribunal referred to the Report of the UN Secretary-General, directly rejecting the guilt of mere membership in the organization, and reaffirmed the principle of individual criminal responsibility stating that "Nobody may be held criminally responsible for acts or transactions in which he has not personally engaged or in some other way participated (nulla poena sine culpa), ${ }^{, 5}$.

The ICTY case law $^{6}$ distinguishes three forms of JCE:

1) Crimes are committed by an individual who is acting under the common design possess the same criminal intent to commit a particular crime shared by all the members. The objective and subjective elements of this form of JCE are as follows: a) an individual shall participate in the realization of one of the aspects of common intent facilitating the actions of co-perpetrators; b) an individual even if he has not personally committed actions constituting the objective side of the crime, should wish the criminal result;

5 ICTY.(15 June, 1999). MTBY: resheniye appelyacionnoy cameri po delu Tadicha (ICTY: Judgment of the Appeals Chamber on Tadić case, in Russian). Paragraph 186.

6 Judicial precedent as a source of law is generally alien to international criminal law. Judicial decisions of international courts, of course, are the sources of the ICL, fulfill the most important function of interpreting the Convention and ordinary norms of the ICL, serve as important evidence of general practice and recognition of the ordinary norms, but not judicial precedents.
2) crimes are committed by a group of people holding various positions in the hierarchy system, acting following an agreed plan and under common intent. A person is aware of the inhuman nature of the system and intends to participate in the activities of this system. Objective and subjective elements of this form of JCE are: a) a person must be in a specific organized system; b) the person is aware of the nature of this system and has a common intention to participate in the implementation of the crime; c) the person actively participates in the work of the system, and any form participates in the implementation of the crime (the so-called "concentration camp situation");

3) the general intent of the person is aimed at participating in the criminal activity or criminal purpose of the group with its contribution to the JCE or the commission of a crime by the group, i.e. crimes committed by other persons, although they are outside the common intent of the person, however, for the person they are the natural and visible consequence of the implementation of a common goal, where each of the participants is responsible for all visible crimes committed by its other participants.

The subjective element is the intention of the person to participate and contribute to any action of the group, including to achieve the criminal goal of a group, where responsibility for a crime that has not been generally agreed upon is established if the person foresaw that such a crime could have been committed by one or several members of the group and willingly took on this risk (the so-called "extended form of JCE"). Awareness of the possibility of committing a crime and willingly accepting its risk excludes a possible reference to the "excessive act". 
Thus, the ICTY has developed the objective elements of a crime (actus reus), common for all three types of the joint criminal enterprise, which should be expressed in the following elements: 1) the multiplicity of persons (JCE exists when there are several persons who take part in the realization of a common criminal goal. They do not have to be mandatory organized in military, political or administrative structure); 2) the existence of a common plan, project or goal that provides for or entails the commission of a crime (The plan, project or purpose does not have to be pre-drawn up or formulated. The agreement or understanding of the people who make up the overall project or purpose need not be specific; they may be not-expressed and established from actual circumstances. The standard plan or purpose may be implemented impromptu and can be established based on the fact that a group of people acts in concert to implement the JCE); 3) the person's participation in the common intent, entailing the commission of one of the crimes. (Participation should not entail the commission of a certain crime (for example, murder, extermination, torture, violence, etc.), but may take the form of assistance or contribution to the fulfilment of the common plan or the realization of the common purpose. As for the elements of the subjective side, both the first and the second form of JCE implies the direct intention of its participants to commit a certain type of crime, where each of the participants in JCE is responsible for all actions arising from the criminal plan. In the third form, the same person may have the intention on the commission of some crimes within the common purpose and recklessness in relation to others which were not part of a common goal but were its foreseeable consequences ${ }^{7}$.

7 ICTY.(15 June, 1999). MTBY: resheniye appelyacion-
For example, as typical participation in the third form of JCE (extended form) is demonstrated in the conclusion of the ICTY Appeal Chamber in the case of Radislav Krstić. In order to hold the accused responsible for actions that are natural and foreseeable consequences of the joint criminal enterprise, there is no need to establish his actual knowledge that these other actions will be committed. It is enough to show that these actions, which were outside the agreed criminal enterprise, were a natural and visible consequence of the agreed criminal enterprise, and that the accused participated in this enterprise, knowing about the likelihood that these other crimes could be committed. It is also not necessary to establish that Radislav Krstić did know about the commission of these other criminal acts. It was enough to show that their commission was visible to him and that these other crimes were actually committed ${ }^{8}$. Thus, the ICTY Appeals Chamber, in the case of M. Krajišnik came to the conclusion that political speeches should be considered as actions that are no different from other actions.

The scientific community for the creation and application of the doctrine of the JCE has been divided, inter alia, into directly opposing positions on evaluating the effectiveness of the practical application of the doctrine of the JCE. Some of them see in the doctrine the principle of "victors' trial over the defeated" or "trial by a biased", others dispute the legitimacy of the conception by the judges of the ICTY, while others point out the amorphous concept, elements and boundaries of the JCE doctrine, etc.

Thus, N. Dershowitz argues that none of the

noy cameri po delu Tadicha (ICTY: Judgment of the Appeals Chamber on Tadić case, in Russian).

8 ICTY.(19 April, 2004). Resheniye appelyacionnoy kameri po delu Krsticha (Judgment of the Appeals Chamber on Krstić case, in Russian). Paragraph 150. 
five types of complicity provided for in Article 7 (1) of the ICTY Statute is "joint criminal enterprise". Instead, the JCE acts like a conglomerate of five types of responsibility, which allows prosecutors and judges to construct some combination of pieces of evidence against the accused in order to convict him of some generalized crimes, without evidence that the accused planned, instigated or otherwise aided or abetted to the commission of any particular crime (Dershowitz, 2012, p. 23).

Although the JCE doctrine is the most complex and controversial theory in international criminal law, in our opinion, such a progressive nature of the doctrine is due to the tendency to commit war crimes among high-level military leaders and political leaders, the difficulty of holding them responsible. It is dictated by the interests of justice, being "a silver bullet of justice" and acting as the only effective means of holding top political and military leaders liable at a strategic level.

In our opinion, acts of planning, preparation, instigating, aiding, issuing criminal orders, their provision and implementation, depending on the circumstances, can be qualified with reference to Article 38 of the Criminal Code of the Republic of Armenia (hereinafter the RA CC) ${ }^{9}$, according to the rules of complicity provided for by national legislation, as an organizer, leader, instigator, accomplice, and in those rare crimes where a form of participation such as an organized criminal group ${ }^{10}$ and criminal community, according to the corresponding aggravating criterion, based on the combination of evidences, un-

9 Criminal Code, A. (29 April 2003). N LR-528.

10 A crime is recognized as committed by an organized group if it is committed by a stable group of persons who have previously united to commit one or more crimes. An organized group is distinguished from a group of persons by prior conspiracy signs of stability and organization. der Article 384 "aggressive war", part 1 of Article 387 of the RA CC "use of means and methods of war prohibited by an international treaty in military operations or armed conflicts", Article 390 of the RA CC "serious violations of international humanitarian law during armed conflicts", point 13 of part 2 of Article 104 of the RA CC "murder out of the motives of national, race or religious hate or fanatism", and in some cases under Article 391 "Inaction or making an illegal command during armed conflict".

However, such forms of participation as an organized criminal group and the criminal community can be imputed, in our opinion, in the event when individuals or organizations commit war crimes, and not by States or their official bodies. Moreover, we believe that the prosecution of representatives of the military-political leadership of an enemy State is currently possible only at the international level. Moreover, based on the definitions developed by international criminal justice authorities, and qualification according to the rules of complicity provided by national legislation will entail insurmountable complexity of proof, in which the process of bringing charges will be practically impossible. Everything will be turned into the dimension of political charges.

In our opinion, there are two mechanisms for holding the military-political leadership of the opposing party liable: 1 ) the defeat of the opposing party and holding the war criminals liable by the victors on the territory of the defeated party; 2) the implementation of the provisions of the doctrine of the JCE in national legislation, bringing national legislation in line with the Rome Statute of the ICC and establishing a procedure for war crimes cases based on the principle of mandatory universal jurisdiction, as well as the organization of interaction and cooperation be- 
tween States, international and national criminal justice bodies.

In order to ensure the $2^{\text {nd }}$ point, as well as, taking into account what it seems to have the utmost importance, in the Chapter XIII of the RA CC incorporate the Article 25 of the Rome Statute of the ICC and concerning war crimes to develop the types and forms of complicity to the provisions of the doctrine of the JCE and other types of complicity, i.e. criminalize such methods of participation in the commission of crimes when several people have a common criminal purpose, which is realized either jointly or by some members of this group, under the practice of international criminal justice bodies. Besides, in order to determine the circle of liable persons, it is necessary to develop an algorithm on the principle of vertical.

So, in order to hold the military-political leadership of the opposing party liable, a military-political hierarchical relationship in the State should be established, i.e. to establish a relationship of persons who, using their power, directing and implementing state policy, in order to execute the strategic criminal plan they have jointly developed, pass their orders down through the military hierarchy of officials at all levels through the chain of military authorities to the perpetrators of the crime and are associated with a multitude of crimes committed in different regions of the armed conflict (since it is not excluded that certain individuals commit a single crime from selfish and other personal motives). It is also necessary to establish this connection in the reverse order, i.e. establish the perpetrators of the crime, and if it is not possible to reveal the identities of the direct perpetrators by name, it is enough to determine the unit in which he serves and climb the chain of military authorities through different levels of the military hierarchy to the political leadership of the country (soldier, commander of a squad, platoon, company, battalion, regiment (brigade), divisions (corps), head of the directorate of certain types of troops, commander of arms and branches of service, Deputy Chief of the General Staff, Chief of the General Staff, Minister of Defense, etc.).

For the implementation of the JCE doctrine, the starting point is the presence of a general plan for the country's military-political leadership of a strategic criminal plan, as can be evidenced by systematic statements penetrated by military rhetoric, persons involved in political activities and holding public office; diplomatic demarches against another State or other administrative entity; contrary to existing treaties, military buildup; uncontrolled acquisition of offensive weapons; the accumulation of weapons and ammunition; creation of food stocks; intensified intelligence against another State; frequent conduct of command post exercises for the deployment of offensive operations; specific actions to use military force against another State or other administrative entity; reconnaissance in battle; approval of military plans, etc. On contributing to the achievement of the common purpose of the JCE through war crimes and making a significant contribution to the JCE through active instigating, evidence may indicate a reluctance to prosecute the perpetrators of the crimes and encouraging such persons to submit for military awards, promotions and other measures aimed at further stimulating the commission of crimes.

Thus, in order to bring the military-political leadership of the opposing party to criminal responsibility for committing war crimes, due to legal certainty and evidentiary prospects, national legislation should adopt the positive experience of international criminal justice authorities regarding the institution of complicity, the doc- 
trine of the JCE and the doctrine of responsibility of commanders, as currently, the only international judicial body capable of considering such cases is the International Criminal Court.

\section{REFERENCES}

Dershowitz, N. (2012). Doktrina "sovmestnikh prestupnikh deystviy" $v$ resheniyakh mezhdunarodnogo tribunala po bivshey Yugoslavii (Doctrine of Joint Criminal Enterprise in Judgements of International Tribunal for Former Yugoslavia, in Russian). Mejdunarodniy tribunal po bivshey Yugoslavii: Deyatelnost. Rezul'tati. Effektivnost. (International Tri- bunal for Former Yugoslavia: Activities, Results, Effectiveness) (pp. 23-30). Moscow: Indrik.

Seth, L. (2020). War. In E. N. Zalta (Ed.), The Stanford Encyclopedia of Philosophy. Retrieved June 25, 2020 from: https://plato.stanford.edu/archives/spr2020/ent ries/war/.

Vakhrushev, V. (1999). Lokal'nye voiny $i$ vooruzhennye konflikty: kharakter $i$ vliyanie na voennoe iskusstvo (Local Wars and Armed Conflicts: the Nature and Influence on the Military Art, in Russian). Voennaya misl' (Military Thought), 4, 20-28. 